\title{
Conflict Management of Village Leader Election Organization in Sampang Regency
}

\author{
Puthut Budi Santoso ${ }^{1}$ Agus Kristiyanto ${ }^{2}$ Joko Widodo $^{3}$ Lukman Yudho Prakoso $^{4}$ Wuri Retno Martani ${ }^{*}$ \\ 1. Administration Doctoral Student, 17 August 1945 University, Surabaya \\ 2. Lecturer in Administration Doctoral Study Program, 17 August 1945 University, Surabaya \\ 3. Lecturer in Administration Doctoral Study Program, 17 August 1945 University, Surabaya \\ 4. Lecturer in Strategy of Sea Defense, Indonesia Defense University, Bogor \\ 5. Peace and Conflict Resolution Magister Student, Indonesia Defense University, Bogor
}

\begin{abstract}
Pilkades is an instrument in the formation of a modern and democratic government. This research aims to (1) know the conflict over the holding of village head elections in Sampang Regency; (2) analyze the handling of conflicts that occur in the election of the Village Head in Sampang Regency; and (3) create an ideal model for organizing village head elections in Sampang Regency. The object of this study is Sampang Regency, which is found to be frequent conflicts in the selection of the Village Head. In this study, the main informants used were those who knew and understood the pilkades in the Regency of Sampang. Test the validity of the data using triangulation tests. The data analysis technique used is Grounded Theory research. The results of the analysis show that (1) the policies in the holding of village head elections in Sampang Regency have not been fully implemented. This is reflected in the incomplete implementation of village head elections by referring to the main elements of the policy; (2) The ideal model of pilkades in Sampang Regency leads to the application of the Social Early Warning System in which the implementation of village head elections is conducted by referring to clear and strict rules.
\end{abstract}

Keywords: conflict, Pilkades [Village Leader Election]

DOI: $10.7176 / \mathrm{PPAR} / 9-12-10$

Publication date: December $31^{\text {st }} 2019$

\section{Introduction}

Village leader election is one instrument in forming modern and democratic government. In Laws Number 6 In 2014 about Village is written that Village Leader Election is conducted simultaneously in all Regency/ City areas. Democratic parties conducted in the smallest regional level have been basically regulated by governmental laws regulations about the methods of village leader organization. So all step sets are begun from forming village leader election committees until the chosen village leader inauguration is hoped proper with the determinations that have been determined. But in the practices, village leader election that has been regulated by governmental laws for today is very difficult to be organized fluently and qualifiedly because playing political importance factors, the importances for grabbing powers than the essences wanted by village leader election, i.e. legitimate village government (Widjaja, 1996).

Talking about general election frauds in Sampang, it looks like to invite us for seeing fraudulent practices that have been emerged as "tradition" by historical basis. In the writer simple notes, at least there are the numbers of political events related to general election in Sampang that can be made as legitimation claim that fraud to fraud have happened for a long time. Moreover general election frauds in Sampang has been begun since 1997 when this republic only knows three parties and reformation order has not been born.

The researcher wills for reviewing deeper about the research object, in this case, village leader election is response from social symptoms that come in the middle of people, especially in Village citizens in Sampang Regency, as the research location. The social symptoms aimed come as new problems that can influence people. Clearly, there are importances or powers and politics that are being run by certain parties. Village people are also political people, who run the power through certain relations. Village leader election execution aimed is considerably influenced by the people in it, including the available candidates, supporters of each candidate, and also the parties involved through certain methods. So, it happens social symptoms such as certain group formation, less good relations, seeking opponent weaknesses each other, showing the abilities respectively, even 
happening conflicts and violences.

Village people still generally uphold kinship values moreover blood relations. Something impossible to elect other people of there are still people who are closer, it means there are blood bindings. Strong solidarity feelings in village people in other side are weaknesses for determining the choices in political contexts later, before village leader election, in village leader election, and after executing the election. This case happens because supported by good chances and same rights for each citizen for electing and also elected.

The writer also sees the happening social conflicts influence all aspects of people daily life Entirely, it impacts on people social relation, even the relations among society members who are like brothers and sisters are influenced by the condition, so the kinship and blood relational values have been faded and very concerning. Because the available candidates are basically the people who still have kinship relations. This case that become interests and backgrounds so the research needs conducting considerably.

\section{Literature Reviews}

\subsection{Social Conflict Theory}

Coser in Zeitlin (1998:156) defined social conflict as some struggle toward values and recognitions toward rare status, then power and conflict sources are neutralized or taken place or eliminated about the competitors. Social conflict is one of social interaction form between one party and other party in society signed by characters of threatening, suppressing, until destroying each other. Social conflict is really some process of meeting two parties or more who have importances that are relatively same toward the cases that characterize as limited. According to Irving (1995:156) he said that generally social conflict contains some sets of conflict and battle phenomena among personals, groups through class conflicts until international conflict and wars. Social conflict is as some struggle toward values and recognitions toward rare status, then power and conflict sources are neutralized or taken place, or eliminated about the competitors. Simon Fisher (2001:7-8) explaines the theories of causing conflicts in society. First, explaining theories of causing conflicts in society. First, theory of society relation, that conflicts that happen are considerably caused by polarization, distrust and hostility among groups in the middle of our society. Second, theory of principle negotiation, that conflicts are caused by the positions that are out of tune and view differences about conflicts among the parties involved in it.

\subsection{General Election}

General election is some process in which electors elect people for filling certain political positions. The positions here are various, beginning from President, people's representatives in many governmental levels, until village leaders. According to Laws Number 3 In 1999 about General election, General election is facility of popular sovereignty execution in Indonesian Republic unity country based on Pancasila and Constitution of 1945. Therefore, the highest power from some country is sourced or derived from people, the Country leaders are chosen upon people wills (Zainul, 2005:541).

General election is one of important requirements in one country that follows democratic system. General election execution becomes general method as facility of distributing popular sovereignty. People have rights and authorities for determining who are the representatives executed in general election. Sukardja (2012:156) expressed that general election in modern system such as today is part of popular sovereignty formation, because people are given political chances for choosing the representatives. According to Asshiddiqie (2007) entirely, the purposes of general election organization are 4 [four], they are:

1. For enabling to happening governmental leadership transition orderly and peacefully.

2. For enabling to happening official substitution that represents people importances in representative institution

3. For executing popular sovereignty principles

4. For executing citizen right principles

\subsection{Village Leader Election}

According to Governmental Regulation Number 72 In 2005, "Village is law society unity that has area limits that authorizes to regulate and manage local people importances, based on local origins and customs recognized and respected in governmental system of Indonesian Republic Unity Country". 
Village government or called by other name as village leader is element of village governmental organization. The village governments aimed are village leader and village officials [Village Secretariat, Field Technical Executor, Area Element].

In Governmental Regulation Number 72 In 2005 about Village, Clause 14 in verse [1] is firmly mentioned that Village Leader has the duties of organizing affairs of government, development and social ones and in verse [2] states that Village Leader has authorities of:

1. Leading village government organization based on the policies stated by Village Consultative Body;

2. Forwarding village regulational designs;

3. Determining village regulations that have gotten agreements by Village Consultative Body;

4. Arranging and forwarding village regulational design about Village Income and Expenditure Budget for discussed and stated by Village Consultative Body;

5. Developing village people life;

6. Coordinating village development participatively;

7. Representing the village inside and outside the court and it can point attorney for representing it according to laws; and

8. Executing other authorities according to laws regulations.

\section{Research Methods}

The research type used is descriptive research by using qualitative approach. Qualitative method is used for getting deeper data, some data that contain meanings (Sugiyono, 2014). In this research, qualitative is used for getting descriptions about research object, i.e. about the causes of conflicts that happen in village leader organization in Sampang Regency, the steps of revamping policies in order to create ideal model in Village Leader election organization.

The research method from this research is survey method. Furthermore, qualitative research used is case study qualitative. Descriptive type of case study qualitative does not have characteristics like water, but focussing on some certain unit from several phenomena. From the characteristics like that enable this study deeper and therefore, data depth become considerations in this model. Therefore, this research characterizes as deeper and "piercing" research targets (Bungin, 2012).

This research object is Sampang Regency gotten that there are many conflicts in Village Leader election. In this research, it uses informants as respondents. In this research, determination of informational sources or informants in the people interviewed is conducted by purposive sampling, i.e. chosen based on certain considerations and purposes. In this research, the main informants used are the parties who considerably know and understand village leader election organization in Sampang Regency. So, the informants used in this research are:

1. National and Political Unity Council in Sampang Regency.

2. Camat in Torjun District.

3. Camat in Banyuates District.

The data analysis technique used is Grounded Theory research conducted by undesigned, but it must not interpreted as random research form (Burhan, 2012). Grounded Theory shoves off from the the methods of thinking inductively, then thinking deductively. This research assumes that data are theory inspirations, then moving to form theories that explain data (Burhan, 2012).

\section{Discussions}

\subsection{Village Leader Election Organizational System in Sampang Regency}

\subsubsection{Village Leader Election Application in Sampang Regency}

Based on the observational results, it shows the problems that happen in village leader election in Banyuates Village Sampang Regency are based on Village Leader candidates who do not complete the Village Leader candidate requirements according to the requirement determination determined, such as in the determination in Governmental Regulation Number 43 In 2014 in clause 41 verse [3] alphabet b number 7 that sounds the aimed by "administrative 
requirement completeness ones" are documents about administrative requirement of candidates, they are identity card and certificate of living at least 1 [one] year before registration from local neighborhood association/citizen association and village leader. So are written in Sampang Regency Regulation Number 31 In 2015 Clause 20 verse [2] alphabet g, i.e. listed as resident and living in local village at least 1 [one] year before registration based on Identity card. One of them includes files about domicile statement so the files are rejected.

If village leader candidate does not meet all requirements determined, so the parties of Village Leader Election Committees authorize to abort the village leader candidate to next nomination processes. Therefore, village leader candidates must meet the requirements that have been determined. In this case, it is related to the statement that the village leader candidates have become the residents in local village less than 1 year before registration based on Identity Card.

Other problems also happen in West Batoporro Village, in which there are village leader candidates rejected in nomination processes because there are mistakes of writing certificated. In one side, administrative requirement in village leader nomination must complete formal educational certificates from elementary level until the last certificates legalized by authorized officials or statement letter from the authorized officials contained in Clause 41 Verse [3] alphabet b. The case shows that mistakes of writing certificates can make the documents invalid and do not meet administrative requirement completeness. The same problems also happen in Kamoning Village, where there are village leader candidates who are aborted because only enclosing Elementary School Registration Number as Elementary School certificate substitute for requirement completeness.

\subsubsection{Village Leader Election Organizational System in Sampang Regency}

1. Purposes

In organizing Village Leader election, Sampang Regency has has clear purposes, such as the interview results conducted by National and Political Unity Council in Sampang Regency that say that Village Leader election organization has had clear purposes. The case is supported by the interview results by Camat in Banyuates District that show that Village Leader election organization has clear purposes, i.e. organized better village government by collecting people aspirations, in which through the village leader election organization, it is hoped to be able to become village people democracy container in the case of freedom to be chosen or choose Village Leader, for leading village government in the future according to people consciences in village.

2. Input

Based on the interview results conducted by several informants, it can be known that human resources in this case are General Election Supervisory Committees who have been adequate and they can support village leader election organizational processes in Sampang Regency. In this case, General Election Supervisory Committees have experiences in coordinating and successing Village Leader election organization. This case is because there are previous experiences becoming General Election Supervisory Committees, but it is still found less neutrality in Village Leader election execution seen from several ones who still take side to certain Village Leader candidates.

Besides experiences, most of General Election Supervisory Committees have also had skills and abilities in Village Leader election organization, in which skills and abilities in organizing Village Leader election are the requirements that must be owned by General Election Supervisory Committees before registering. However, there are still found about General Election Supervisory Committes in certain areas who are strong in defending certain groups. Besides seen from human resources, input in some system is also seen from instrumental resources, in which the instruments have been adequate and supported Village Leader election execution processes.

3. Processes

a. Village Leader Election Organization According to Standards

Village leader election in Sampang Regency has owned standardization and proper with regulational determination in Sampang Regency, but it needs revising about Regional Regulation understandings especially in nomination requirement such as domicile requirement contained in minimal detemination of candidate has lived in election area for one year.

b. Communication Intertwined in Village Leader Election Organization

Although intertwined communication quite fluently, but if not knowing well is also vulnerable to conflict. Communication intertwined between village leader candidates and people who elect them is 
known as quite well because supported by effective communication medias. Besides that, there are also coordinations conducted only the times given are less adequate.

c. Organizational Structure Suitability

Organizational structure of village leader election executor committees has been made according to the requirements in Village Leader election organization by referring to valid regulations. Besides that, organizational structure determination of Village Leader election committees is also made proper with the respective skill, but it needs tight controls in order to anticipate certain candidate selection indication that attempts to abort files. Besides organizational structure arrangement proper with requirements, each Village Leader election executor committee is also obligated to run the duties by responsibilities and based on discipline characters. However, there are still Village Leader election executor committees who run the duties without based on discipline characters, in which there are still people who are not neutral and take sides.

d. Characters of Village Leader Election Organizational Executor/Committee

Most of executor committees are spry in running each Village Leader election process in giving explanations when there are not understandings.

e. Socio-Economical and Political Conditions

Environmental condition influences and follows to trigger happening conflicts in Village Leader election. Besides environmental condition factors, economical condition factors also become the important in the influences toward the happening conflicts of Village Leader election organization. Economical condition that influences toward happening conflicts is based on the lower the local people economics, so they are easier and easier to be influenced in electing Village Leader candidates by money political indication that gives agreement of bribing someone so that the person does not run the rights for electing and so that the person runs the rights by certain methods when Village Leader election runs. Besides that, political condition factors also follow to trigger happening conflicts in Village Leader election, in which each Village Leader candidate has wills for winning competitions in grabbing power, so it is vulnerable to conflict.

\section{Output}

System execution in village leader election organization is not separated from happening conflicts, in which the case is caused by the characters of executors, i.e. committees who characterize as less neutral or take sides to one of village leader candidates.

\section{Control Mechanism}

Controls in village leader election organization has been conducted proper with the valid regulations and also tupoxies of each supervisory member. Village leader election organizational controls have been maximal and proper with the determinations because there are witnesses, in which the committees in charges are gained through Village Consultative Body in order to avoid and anticipate happening conflicts. In other side, there is not tight sanction to cheaters in Village Leader election organization, in which giving sanctions does not characterize as punishment, but only explanations to the parties who are less satisfied, so it can cause happening conflicts in Village Leader election organization.

6. Feedbacks

It needs revising in village leader election organizational system that considerably cares socialization before execution in longer times accompanied by internal supervisory teams who control all activities in village leader election organization beginning from committee election. Socialization is important to do in village leader election organization especially in committee election in order to be accompanied by supervisory teams who control running committee election in order to be more transparent and characterize as neutral to village leader candidates.

\subsection{Managing Conflicts that Happen in Village Leader Election Organization in Sampang Regency}

\subsubsection{Importances of Managing Conlicts in Village Leader Election Organization in Sampang Regency}

The attempts of solving conflicts boil down to how to attempt so that the conflicts are in optimal situations, so the conflicts can prevent congestions, stimulate creativities, enable to release tension and initiate changes. If conflicts are not managed well and completely, so it can disturb resource balances and tense relations among the 
people involved. Failures in managing conflicts can refer to effects that harm, therefore, it needs seriosities in managing conflicts. In this case, managing conflicts in village leader election organization is very important to do in order not to impact on the election results not neutral, in which when the conflicts happen and are not managed soon, it will make people use the voting rights for choosing improper with consciences.

\subsubsection{Mechanism of Managing Conflicts in Village Leader Election Organization in Sampang Regency}

The attempts conducted in managing the conflicts that happen in Village Leader election are by forwarding discussions for achieving consensus in conflict solutions that happen, in which the case is conducted by holding meetings for interpreting the contents of Regent Regulations and Regional Regulations that regulate Village Leader Election. This case shows that the solution types are conducted by using deliberations and mediations, in which mediations are conducted by involving Regional Secretary, Committee Chairman, Regional Leader Forum and also Camat. In managing the conflicts, there are mechanisms conducted in order to manage Village Leader election conflicts, they are:

1. Summons to Regency Government administratively.

2. In the meetings, it will be discussed about the problems viwed from Regional Regulation and Regent Regulation.

3. If unsatisfied, there are second invitations for conducting meetings.

After there are the mechanisms, there are the steps that are conducted in managing the conflicts available. The steps are begun by solutions deliberately from village level forwarded in the meetings with the supervisors of District and Regency and if not finding solutions, it will be pursued by laws. Then the interview results conducted by Camat in Torjun District and Camat in Banyuates District give the steps of completing Village Leader election conflicts, they are:

1. Observing informations about the conflicts that happen.

2. Mediation by calling the parties who feel that the decisions are not fair.

3. Making talks by elements of Subdistrict Leadership Meeting firstly if it cannot be overcome, so it will be taken to Subdistrict Leadership Meeting.

4. Taking legal route if not finding bright spots.

\subsection{Ideal Model of Village Leader Election Organization in Sampang Regency}

The main step in meeting ideal model is village leader committee election that characterizes as neutral. In this case, the model of Village Leader Election Organization in Sampang Regency is by real application of Social Early Warning System, in which through early warning especially in village leader election committee election and determination, it will be able to be used as the attempts of minimizing the conflicts that happen, remembering there are still committees who are not neutral or take sides one of village leader candidates.

Social Early Warning System is conducted by ensuring for organizing village leader election based on Laws and other regulations such as Laws Number 6 In 2014 about Village, Indonesian Republic Home Affairs Minister Regulation Number 112 In 2014 about Village Leader Election, Sampang Regency Regional Regulation Number 1 In 2015 about Guide of Nomination, Election, Appointment, Inauguration, and Discharge of Village Leader.

In this case, Social Early Warning System is conducted by adding longer socialization times in order to introduce the regulations available to village leader candidates and to committees available. This case is conducted so that village leader candidates and committees can understand clearly about the requirements, the determinations in becoming Village Leader. Besides that, socialization is very important to be done, because if it happens regulation and step misunderstandings, it will impact on the final results and village leader election successes in the future, even because of unknowing people, it will have potencies of emerging conflicts in society.

Besides longer socialization, Social Early Warning System can be also conducted by forming monitoring teams for ensuring so that socialization is really conducted proper with the regulations available. Besides that, monitoring teams also needs to be formed for monitoring running village leader election organization committee election. The case is conducted in order to anticipate the committees who are not neutral and take sides one of village leader candidates. In this case, the committees are formed by Village Consultative Body accompanied by internal monitoring teams that can ensure that village leader election committees do not have whatever relations to village leader candidates. 


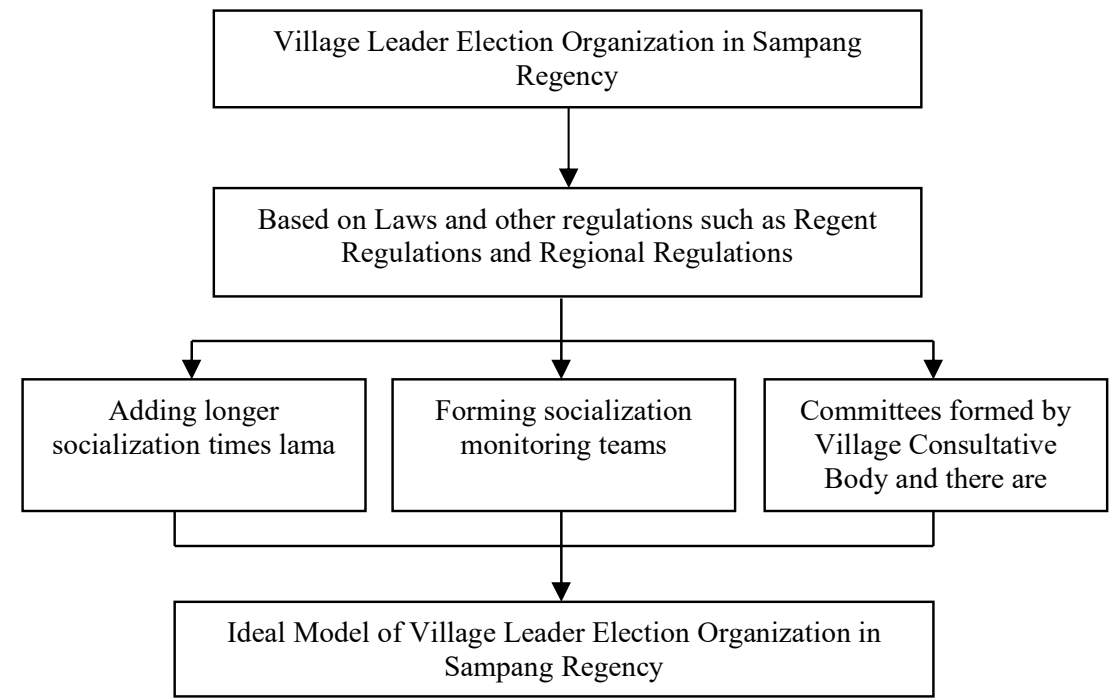

Figure 1. Ideal Model of Village Leader Election Organization in Sampang Regency

\subsection{Propositions}

Based on the theories above and the explanations available, so it can be arranged the propositions as follows:

a. Village Leader Election Organization can be avoided from conflicts if having integrated control systems.

b. Village Leader Election Organization model by doing application of Social Early Warning System will be able to prevent happening conflicts.

\section{Conclusion}

\section{Village Leader Election Organization System in Sampang Regency}

The review results achieved in which system mechanism of Village Leader election organization in Sampang Regency have not been fully conducted well. The case is seen there is output that has negative impacts, i.e. the conflicts that happen among people in village leader election organization caused by the processes that slightly run well. However, the input seen from resources has been adequate and supported in village leader election organization. Human resource such as General Election Supervisory Committee adequate is seen from skills, abilities and experiences in coordinating Village Leader Election organization. However, it is still found that less netrality in Village Leader Election organization is seen from several parties that still take sides to certain Village Leader candidate groups. So, the processes of some certain village leader election organization system are seen from:

a. Village Leader Election Organization is Proper with Standard

Village leader election conducted in Sampang Regency has run proper with regulations both Regional Regulation of Sampang Regency Number 32 In 2002 about The Procedures of Nomination, Election, Inauguration and Discharge of Village Leader and Regent Regulation Number 31 In 2015 about Village Leader Election, but there are still interpretation differences about Regional Regulation understandings especially in nomination requirement such as domicile requirement in which there is determination that minimally the candidates have lived in election regions for one year. Besides that, there is no sanction by law enforcement officers to cheaters in leader village organization that causes many conflicts in Village Leader election.

b. Communication Intertwined in Village Leader Election Organization

Although there is intertwined good communication among Village Leader Candidated, but there are candidates who have not known yet so it is vulnerable to conflict. Besides that, in village leader election organization, it needs supporting by coordination conducted by reports and announcements to law enforcement officers about Village Leader candidate activities, but the times given are still insufficient so 
the understandings about regulations of leader village election have not been still understood in detail in success teams of Leader Village candidates.

c. Organizational Structure Suitability

Organizational structures of village leader election executor committees have been met proper with the requirements in Leader Village election organization by referring to valid regulations. Besides that, organizational structure determination of Village Leader election committees is also made proper with respective skill, but it needs supporting by tight supervision, in order to anticipate certain candidate selection indication that attempts to abort in filling. Besides that, it is known that there are still executor committees in running tasks without discipline characters, in which there are still people who are not neutral and take sides.

d. Executor/Committee Characters of Village Leader Election Organization

Most of executor committees are spry in running each Leader Village election process that takes place, but there is also found several committees who are less spry in Village Leader election organization process.

e. Socio-Economical and Political Conditions

Environmental conditions influence and follows to trigger happening conflicts in Village Leader election, in which low education of most people can impact on easily affected in electing Village Leader candidates by ignoring the rights in electing proper with the choices. Besides that, economical condition factors also become the important in the influences toward happening conflicts of Village Leader election organization, in which the lower the local people economics, so the easier to be influenced in electing Village Leader candidates by indications of money politics that gives agreements of bribing someone so that the person does not run the rights for electing and so that someone runs the rights by certain methods when there is Village Leader election.

\section{Conflict Management in Village Leader Election Organization in Sampang Regency}

Basically, there are many methods for managing conflicts that happen. However, in conflicts that happen in village leader election organization, it considerably refers to conflict management that puts forward discussions for achieving consensus in conflict solution that happens. The case is conducted by holding meetings for interpreting Regent Regulation and Regional Regulation contents that regulate Village Leader election.

\section{Ideal Model of Village Leader Election Organization in Sampang Regency}

Ideal village leader election model in Sampang Regency refers to application of Social Early Warning System in which village leader election organization is conducted by referring to clear and firm regulations so that there are perception similarities in understandings about valid Regent Regulation and Regional Regulation in order not to be found about interpretation misunderstandings about the Regent Regulation and Regional Regulation contents then validated tight controls for village leader election committee in order not to take sides. In this case, ideal model of village leader election organization in Sampang Regency is based on other Laws and regulations such as:

a. Laws, i.e. Laws Number 6 In 2014 About Village.

b. Indonesian Republic Governmental Regulation Number 43 In 2014 about Laws Execution Regulation Number 6 In 2014 About Village.

c. Regent Regulation, i.e. Sampang Regent Regulation Number 31 In 2015 About Guide of Nomination, Election, Appointment, Inauguration and Discharge of Village Leader

d. Regional Regulation, i.e. Sampang Regency Regional Regulation Number 1 In 2015 About Guide of Nomination, Election, Appointment, Inauguration, and Discharge of Village Leader and Sampang Regency Regional Regulation Number 2 In 2015 About Village Governmental Organization.

Based on the available regulations, ideal model of village leader election organization should be also conducted through improvements in longer socializational time additions in order to be able to give more detailed understandings to people and also village leader election executors. Then it can also form socialization monitor teams who move to see whether socialization has been executed proper with the available regulations. Then committees formed by Village Consultative Body are considerably tightened up by monitoring teams for preventing the committees who take side one of Village Leader Candidate groups. 


\section{References}

Asshiddiqie, J. Asshiddiqie. (2007), "Pokok-Pokok Hukum Tata Negara Indonesia”, PT Bhuana Ilmu Populer, Jakarta.

Bungin. B. (2012), “Analisis Data Penelitian Kualitatif”. Raja Grafindo, Persada, Jakarta.

Fisher, S. (2001), “Mengelola Konflik: Ketrampilan \& Strategi Untuk Bertindak”, The British Council, Jakarta

Governmental Regulation Number 43 In 2014 in clause 41 verse [3] alphabet b number 7 that sounds the aimed by "administrative requirement completeness"

Governmental Regulation Number 72 In 2005 about Village

Irving, Z. M. (1995), “Memahami Kembali Sosiologi”, Gadjah Mada University Press, Yogyakarta.

Laws Number 3 In 1999 about General Election

Laws Number 6 In 2014 about Village

Regent Regulation Number 31 In 2015 About Village Leader Election

Sampang Regency Regional Regulation Number 1 In 2015 about Nomination Guide

Sampang Regency Regional Regulation Number 1 In 2015 About Nomination, Election, Appointment, Inauguration

Sampang Regency Regional Regulation Number 2 In 2015 About Village Governmental Organization

Sampang Regency Regional Regulation Number 32 In 2002 about The Methods of Nomination, Election, Inauguration, and Discharge of Village Leader

Sugiyono. (2014), "Metode Penelitian Kuantitatif, Kualitatif, dan Kombinasi (Mixed Methods)", Alfabeta, Bandung.

Sukardja, A. (2012), “Hukum Tata Negara dan Hukum Administrasi Negara”, Sinar Grafika, Jakarta.

Widjaja, A. (1996), "Pemerintahan Desa dan Administrasi Desa Menurut Undang-Undang Nomor 5 Tahun 1979 (sebuah Tinjauan)", PT Raja Grafindo Persada, Jakarta. 